\title{
Liver resection for young patients with large hepatocellular carcinoma: a single center experience from China
}

Xi-yu Liu and Jiang-feng $\mathrm{Xu}^{*}$

\begin{abstract}
Background: To investigate retrospectively the clinicopathological characteristics and outcomes of young patients with large hepatocellular carcinoma after hepatectomy.

Methods: From January 2003 to December 2012, a total of 153 patients with large hepatocellular carcinoma (HCC) who received liver resection were included in the study. The clinicopathological features were analyzed retrospectively. The perioperative data were compared between those aged $<40$ years (the young group) and those aged $>40$ years (the older group). Prognostic factors and long-term survival were evaluated.

Results: The young group had more hepatitis B virus-related HCC than the older group ( $87.2 \%$ vs $66.3 \%, P=0.031)$. In the young group, 15 patients (21.5\%) were overweight (body mass index 25 to $29.9 \mathrm{~kg} / \mathrm{m}^{2}$ ) or obese (body mass index $\geq 30 \mathrm{~kg} / \mathrm{m}^{2}$ ), and 38 patients (45.8\%) were overweight or obese in the older group $(P=0.032)$. Other clinicopathological characteristics were similar between the two groups. The perioperative data showed that the older group had more pulmonary infection after hepatectomy. Vascular invasion and high Edmondson-Steiner grade were the independent prognostic factors for long-term survival. There was no statistical difference between the young group and the older group in overall survival and disease-free survival ( $P=0.109$ and $P=0.087$, respectively).
\end{abstract}

Conclusions: Liver resection for young patients with large HCC was safe and efficacious and should be recommended.

Keywords: Liver resection, Young patients, Large hepatocellular carcinoma

\section{Background}

Hepatocellular carcinoma $(\mathrm{HCC})$ is one of the most common malignancies worldwide, especially in China. HCC ranks second as a cause of cancer death overall in China [1-4]. Many studies have reported that hepatectomy could be performed satisfactorily for large HCC $(>5 \mathrm{~cm})$ with acceptable mortality [5-7]. However, there are few reports about the clinicopathological features and outcomes in young patients with large HCC after hepatectomy, and the significance of hepatectomy for these patients therefore remains unknown.

In USA and Europe, which are not hepatitis B endemic areas, patients younger than 40 years of age with large $\mathrm{HCC}$ are reported to be rare;however, young patients with

\footnotetext{
* Correspondence: zjxujiangfeng@hotmail.com
Department of surgery, Yiwu Affiliated Hospital of Zhejiang University School

* Correspondence: zjxujiangfeng@hotmail.com of Medicine, east building in huajiachi campus,kaixuan road 268, 310020 Hangzhou, Zhejiang, China
}

large HCC are not uncommon in China. To investigate the clinicopathological features as well as the long-term outcomes after hepatectomy of young patients with large HCC, we performed a retrospective study of patients with large HCC undergoing hepatectomy whose ages were younger than 40 years (the young group), compared to those patients aged above 40 years (the older group).

\section{Methods}

From January 2003 to December 2012, 153 patients with large HCC $(>5 \mathrm{~cm})$ were treated surgically in the Affiliated Hospital of Zhejiang University School of Medicine. Patients younger than 40 years of age $(n=70)$ were defined as the young group And patients aged above 40 years $(n=83)$ were defined as the older group. Preoperative evaluation protocol included blood biochemistry, chest radiography, liver and renal function tests, ultrasonography, 
contrast computed tomography and indocyanine green clearance test.

Liver resection was undertaken in the patients with good cardiopulmonary and renal function, Pugh-Child's grades $\mathrm{A}$ and $\mathrm{B}$, and indocyanine green test at $15 \mathrm{~min}<15 \%$.

All intraoperative and postoperative complications were reviewed retrospectively through medical records. Complications (Clavien-Dindo gradesI-V) contained ascites, wound infection, pleural effusion, pulmonary infection, biliary fistula, liver failure and bleeding. Follow-up data were obtained by direct communication with patients after they underwent hepatic resection. All patients were examined for recurrence by clinical examination, alphafetoprotein (AFP) and ultrasonography. The follow-up period was calculated from the date of surgery to the date of either death or last follow-up. Prior informed consent was obtained from all patients and the study was approved by the Ethics Committee of Yiwu affiliated hospital of zhejiang university school of medicine.

Continuous variables were expressed as mean \pm SD and compared using the independent-samples $t$ test. Categorical data analysis used the rank test or chi-square test. Survival analysis, including overall survival and diseasefree survival, was estimated by the Kaplan-Meier survival method and compared using the log-rank test. Univariate and multivariate analysis by the Cox proportional hazard regression model was used to identify independent prognostic factors. All statistical analyses were performed using

Table 1 Clinicopathologic features of 153 patients with large hepatocellular carcinoma

\begin{tabular}{|c|c|c|c|}
\hline \multirow[t]{2}{*}{ Variables } & \multicolumn{3}{|c|}{ Mean \pm SD or number $(\%)$ of patients } \\
\hline & Young group $(n=70)$ & Older group $(n=83)$ & $P$ value \\
\hline \multicolumn{4}{|l|}{ Gender } \\
\hline Female & $17(24.2 \%)$ & $11(13.3 \%)$ & \multirow[t]{2}{*}{0.196} \\
\hline Male & $53(75.8 \%)$ & $72(86.7 \%)$ & \\
\hline Age (years) & $32 \pm 5$ & $55 \pm 9$ & $<0.001$ \\
\hline \multicolumn{4}{|l|}{ Hepatitis B status } \\
\hline Negative & $9(12.8 \%)$ & 28(33.7\%) & \multirow[t]{2}{*}{0.031} \\
\hline Positive & $61(87.2 \%)$ & $55(66.3 \%)$ & \\
\hline \multicolumn{4}{|l|}{ Capsular formation } \\
\hline Presence & $32(45.7 \%)$ & $29(34.9 \%)$ & \multirow[t]{2}{*}{0.535} \\
\hline Absence & $38(54.3 \%)$ & $54(65.1 \%)$ & \\
\hline \multicolumn{4}{|l|}{ Tumor number } \\
\hline Single & $49(70.0 \%)$ & $60(72.3 \%)$ & \multirow[t]{2}{*}{0.654} \\
\hline Multiple & $21(30.0 \%)$ & $23(27.7 \%)$ & \\
\hline \multicolumn{4}{|l|}{ AFP level } \\
\hline Negative & $21(30.0 \%)$ & $32(38.5 \%)$ & \multirow[t]{2}{*}{0.616} \\
\hline Positive & 49 (70.0\%) & $51(61.5 \%)$ & \\
\hline \multicolumn{4}{|l|}{ Liver cirrhosis } \\
\hline Absent & $38(54.3 \%)$ & $44(53.0 \%)$ & \multirow[t]{2}{*}{0.851} \\
\hline Present & $32(45.7 \%)$ & $39(47.0 \%)$ & \\
\hline \multicolumn{4}{|l|}{ Child-Pugh classification } \\
\hline A & $56(80.0 \%)$ & $73(87.9 \%)$ & \multirow[t]{2}{*}{0.762} \\
\hline B & $14(20.0 \%)$ & $10(12.1 \%)$ & \\
\hline Tumor size (cm) & $7.3 \pm 2.1$ & $7.9 \pm 2.7$ & 0.801 \\
\hline \multicolumn{4}{|l|}{ Vascular invasion } \\
\hline Absent & $37(52.8 \%)$ & $49(59.0 \%)$ & \multirow[t]{2}{*}{0.837} \\
\hline Present & $33(47.2 \%)$ & $34(41.0 \%)$ & \\
\hline \multicolumn{4}{|l|}{ BMl } \\
\hline Normal weight & $55(78.6 \%)$ & $45(54.2 \%)$ & \multirow[t]{2}{*}{0.032} \\
\hline Overweight/obese & $15(21.4 \%)$ & $38(45.8 \%)$ & \\
\hline
\end{tabular}

$P$ values in bold indicate statistical significance between groups. AFP, alpha-fetoprotein; BMI, body mass index. 
statistical software (SPSS 13.0 for Windows;SPSS, Chicago, IL, USA). $P<0.05$ was considered to be statistically significant.

\section{Results}

Clinicopathologic features of patients with large hepatocellular carcinoma

The clinicopathologic parameters of the 153 patients with large $\mathrm{HCC}$ who underwent liver resection are shown in Table 1. The age of the young group was $32 \pm 5$ years compared to $55 \pm 9$ years in the older group. In the young group, 61 patients $(87.2 \%)$ had positive hepatitis B in serologic test results; however, only 55 patients (66.3\%) had positive hepatitis B in the older group. In the young group, 15 patients $(21.4 \%)$ were overweight (body mass index (BMI) 25 to $29.9 \mathrm{~kg} / \mathrm{m}^{2}$ ) or obese (BMI $\geq 30 \mathrm{~kg} / \mathrm{m}^{2}$ ), and 38 patients $(45.8 \%)$ were overweight or obese in the older group $(P=0.032)$. Clinicopathologic characteristics, including size of tumor, vascular invasion, tumor number, capsular formation, AFP level, liver cirrhosis, and ChildPugh classification, showed no statistical difference between two groups.

\section{Perioperative data}

The intraoperative and postoperative data of 153 patients with large HCC who underwent liver resection are shown in Table 2. In the young group, non-anatomical resection was used in $31(44.3 \%)$ patients, and 39 patients (55.7\%) patients had hemihepatectomy or extended hemihepatectomy. In the young group, the surgical resection margin was $\leq 1 \mathrm{~cm}$ in $34(48.6 \%)$ patients compared to $39(47 \%)$ patients in the older group. The time for hepatic resection was $188 \pm 9$ minutes in the young group compared to $193 \pm 23$ minutes in the older group. The volume of blood loss was $1,196 \pm 638 \mathrm{ml}$ in the young group with $36(51.4 \%)$ patients losing $<1,000 \mathrm{ml}$ compared to $1,226 \pm 768$ in the older group with 39 (47\%) patients losing $<1,000 \mathrm{ml}$. In the young group, 32 (45.7\%) patients had no blood transfusion, the length of hospital stay was $14 \pm 5$ days with no hospital death, and the overall postoperative complication rate was $23 \%$ (16 patients). In the older group, $30(36.1 \%)$ patients had no blood transfusion, the length of hospital stay was $16 \pm 7$ days, and the overall postoperative complication rate was $22.9 \%$ (19 patients).

\section{Postoperative complications}

There was no significant difference in the overall postoperative complication rate between the two groups (23\% vs $22.9 \%, P=0.928$; Table 3 ). The common complications of the two groups were ascites, wound infection, pleural effusion, pulmonary infection, biliary fistula, liver failure and bleeding. The most common complication in the young group was bleeding (8.6\%), and the most common complication in the older group was pulmonary infection (13.3\%). Pulmonary infection showed a significant difference between the two groups $(P=0.041)$. The only postoperative death was caused by liver failure in the older group (Table 3).

Table 2 Perioperative data

\begin{tabular}{lcc}
\hline Variables & \multicolumn{2}{c}{ Mean \pm SD or number (\%) of patients } \\
\cline { 2 - 3 } & Young group $(\mathbf{n}=\mathbf{7 0})$ & Older group ( $\mathbf{n}=\mathbf{8 3})$ \\
\hline Type of surgical resection & $31(44.3 \%)$ & $36(43.4 \%)$ \\
$\quad$ Non-anatomical resection & $39(55.7 \%)$ & $47(56.6 \%)$ \\
$\quad$ Hemihepatectomy/extended hemihepatectomy & & 0.756 \\
Surgical resection margin (cm) & $34(48.6 \%)$ & $39(47 \%)$ \\
$\quad \leq 1$ & $36(51.4 \%)$ & $44(53 \%)$ \\
$>1$ & $188 \pm 9$ & $193 \pm 23$ \\
Operative time (minutes) & $13 \pm 11$ & $15 \pm 13$ \\
Time for inflow occlusion (minutes) & $1,196 \pm 638$ & $1,226 \pm 768$ \\
Blood loss (ml) & $36(51.4 \%)$ & $39(47 \%)$ \\
$\quad<1,000$ & $34(48.6 \%)$ & $44(53 \%)$ \\
$\quad 1,000$ & & 0.936 \\
Blood transfusion (patients) & $38(54.3 \%)$ & 0.673 \\
$\quad$ With & $32(45.7 \%)$ & 0.475 \\
Without & 0 & $53(63.9 \%)$ \\
Hospital mortality & $16(23.0 \%)$ & $30(36.1 \%)$ \\
Complications & $14 \pm 5$ & $1(1.2 \%)$ \\
Hospital stay (days) & $19(22.9 \%)$ \\
\hline
\end{tabular}


Table 3 Postoperative complications

\begin{tabular}{lccc}
\hline \multirow{2}{*}{ Complications } & \multicolumn{2}{c}{ Number (\%) of patients } & \\
\cline { 2 - 3 } Young group & Older group & P value \\
\hline Overall & $16(23.0 \%)$ & $19(22.9 \%)$ & 0.928 \\
Ascites & $2(2.8 \%)$ & $1(1.2 \%)$ & 0.326 \\
Wound infection & $2(2.8 \%)$ & $2(2.4 \%)$ & 0.657 \\
Pleural effusion & $1(1.4 \%)$ & $1(1.2 \%)$ & 0.536 \\
Pulmonary infection & $1(1.4 \%)$ & $11(13.3 \%)$ & $\mathbf{0 . 0 4 1}$ \\
Biliary fistula & $2(2.8 \%)$ & $1(1.2 \%)$ & 0.326 \\
Liver failure & $2(2.8 \%)$ & $1(1.2 \%)^{*}$ & 0.326 \\
Bleeding & $6(8.6 \%)$ & $2(2.4 \%)$ & 0.084 \\
\hline
\end{tabular}

${ }^{*}$ Caused postoperative death. $P$ values shown in bold indicate statistical significance between groups.

Long-term survival and prognostic factors of patients with large hepatocellular carcinoma after hepatectomy The 1-, 3-, and 5-year overall survival rates in the young group were $93 \%, 79 \%$ and $47 \%$. The 1-, 3-, and 5-year disease-free survival rates in the young group were $87 \%$, $28 \%$ and $17 \%$. The 1-, 3-, and 5-year overall survival rates in the older group were $85 \%, 75 \%$ and $40 \%$. The $1-$, 3-, and 5 -year disease-free survival rates in the older group were $65 \%, 36 \%$ and $11 \%$. Overall survival and disease-free survival in the young group and the older group were similar $(P=0.109$ and $P=0.087$, respectively; Figure 1$)$.

Variables that might affect overall survival of young patients with large $\mathrm{HCC}$ after hepatic resection were also analyzed in this study (Table 4). Univariate analysis of the prognostic factorsfound that patients with liver cirrhosis $(P=0.045)$, vascular invasion $(P=0.017)$ and high Edmondson-Steiner grade $(P=0.036)$ had poorer overall survival than those without these variables. However, using multivariate analysis of the prognostic factors that predicted overall survival status, only presence of vascular invasion $(P=0.031)$ and high Edmondson-Steiner grade $(P=0.042)$ was significant (Table 4$)$.

\section{Discussion}

Young patients with large HCC, who are rare in USA and Europe, are not uncommon at diagnosis in China. Astudy showed that $30 \%$ of HCC patients were younger than 40 years old [8]; in our cohort this ratio reached $47 \%$. The high liver cancer rates in young patients in China largely reflect the prevalence of chronic hepatitis $B$ virus (HBV) infection [9-11]. In this study, the young group had more HBV-related HCC than the older group (87.2\% vs66.3\%, $P=0.031)$. This implied that HCC in most young patients was caused by HBV infection. This infection may even have happened in infancy and has caused liver cirrhosis after many years. HBV infection leads to HCC [12-15]; therefore, regular examination of AFP and B ultrasound is very important for young patients with a history of hepatitis B infection. It is key for an early diagnosis and early operative treatment to improve the survival rate of young HCC patients. In the older group, there may be other factors involved. In the young group, 15 patients (21.4\%) were overweight (BMI 25 to $29.9 \mathrm{~kg} /$ $\mathrm{m}^{2}$ ) or obese $\left(\mathrm{BMI} \geq 30 \mathrm{~kg} / \mathrm{m}^{2}\right)$, compared to 38 patients (45.8\%) in the older group $(P=0.032)$. It is implied that non-alcoholic fatty liver diseases, which are associated with obesity, may participate in the development of HCC, especially in older patients [16-19]; therefore, we must pay more attention to the older patients who are overweight or obese.

Our study showed that hepatic resection for large HCC could be performed with an acceptable mortality rate and postoperative complication rates. The perioperative data
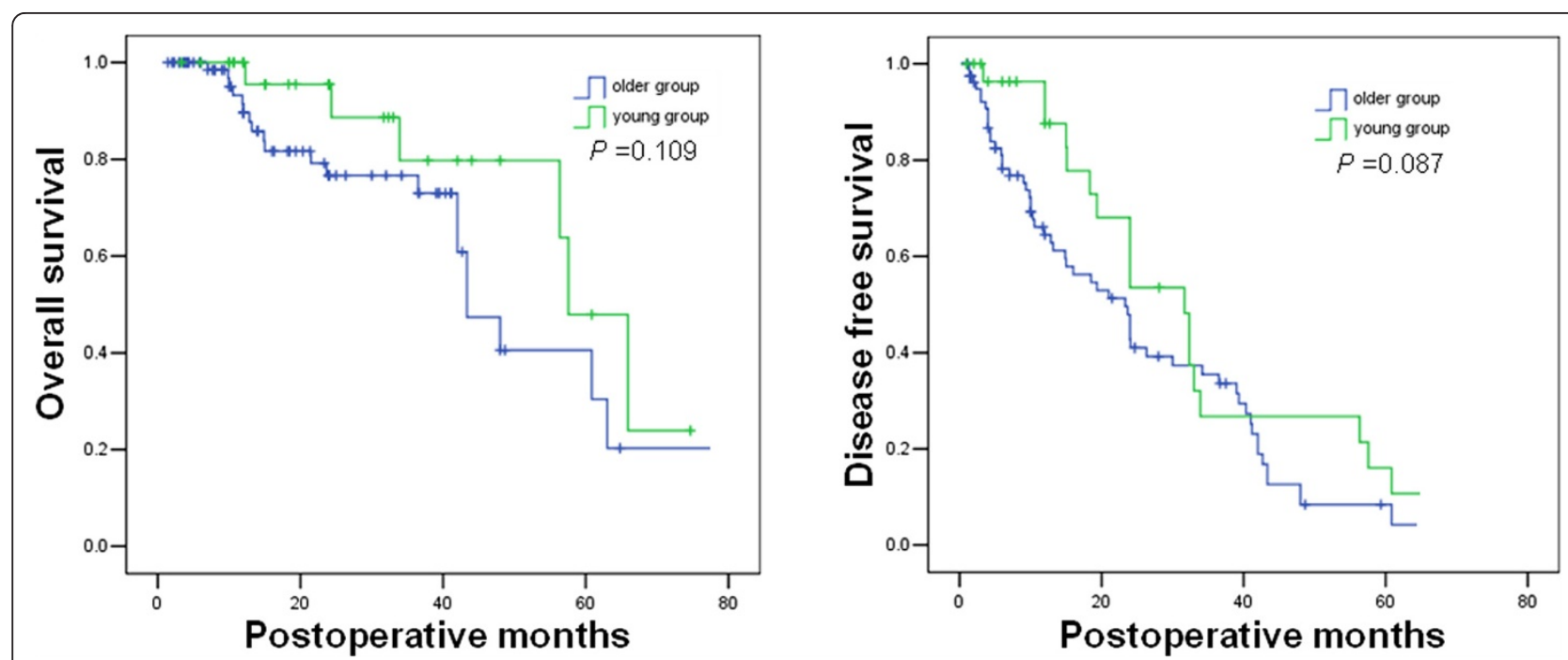

Figure 1 Cumulative overall and disease-free survival curves after hepatectomy of the young and older patients with large hepatocellular carcinoma. 
Table 4 Cox proportional hazard regression analyses for overall survival in young patients with large hepatocellular carcinoma after hepatectomy

\begin{tabular}{|c|c|c|c|c|c|}
\hline \multirow[t]{2}{*}{ Variables } & \multirow[t]{2}{*}{$\mathrm{n}^{*}$} & \multicolumn{2}{|c|}{ Univariateanalysis } & \multicolumn{2}{|c|}{ Multivariate analysis } \\
\hline & & HR $(95 \% \mathrm{Cl})$ & $P$ value & HR $(95 \% \mathrm{Cl})$ & $P$ value \\
\hline \multicolumn{6}{|l|}{ Gender } \\
\hline Female & 17 & 1 & & 1 & \\
\hline Male & 53 & $0.752(0.290-3.547)$ & 0.548 & $0.721(0.309-3.176)$ & 0.408 \\
\hline \multicolumn{6}{|l|}{ Hepatitis B status } \\
\hline Positive & 61 & 1 & & 1 & \\
\hline Negative & 9 & $0.963(0.243-4.416)$ & 0.363 & $0.904(0.262-3.455)$ & 0.789 \\
\hline \multicolumn{6}{|l|}{ AFP level (ng/mL) } \\
\hline Negative & 21 & 1 & & 1 & \\
\hline Positive & 49 & $1.006(0.561-1.012)$ & 0.053 & $1.069(0.972-1.108)$ & 0.129 \\
\hline \multicolumn{6}{|l|}{ Number of tumors } \\
\hline Single & 49 & 1 & & 1 & \\
\hline Multiple & 21 & $1.351(0.739-2.146)$ & 0.053 & $1.683(0.460-2.373)$ & 0.112 \\
\hline \multicolumn{6}{|l|}{ Liver cirrhosis } \\
\hline Absent & 38 & 1 & & 1 & \\
\hline Present & 32 & $1.114(1.058-2.934)$ & 0.045 & $1.137(0.866-2.798)$ & 0.207 \\
\hline \multicolumn{6}{|l|}{ Child-Pugh classification } \\
\hline A & 56 & 1 & & 1 & \\
\hline B & 14 & $1.237(0.762-2.387)$ & 0.508 & $1.119(0.428-3.946)$ & 0.623 \\
\hline \multicolumn{6}{|l|}{ Vascular invasion } \\
\hline Absent & 37 & 1 & & 1 & \\
\hline Present & 33 & $2.112(1.037-3.896)$ & 0.017 & $2.233(1.010-4.232)$ & 0.031 \\
\hline \multicolumn{6}{|l|}{ Edmondson-Steiner grade } \\
\hline Low grade (I and II) & 34 & 1 & & 1 & \\
\hline High grade (III and IV) & 36 & $1.560(1.087-3.331)$ & 0.036 & $1.747(1.235-3.346)$ & 0.042 \\
\hline \multicolumn{6}{|l|}{ Surgical resection margin } \\
\hline$\leq 1 \mathrm{~cm}$ & 34 & 1 & & 1 & \\
\hline$>1 \mathrm{~cm}$ & 36 & $1.339(0.234-3.642)$ & 0.743 & $1.366(0.356-2.956)$ & 0.375 \\
\hline \multicolumn{6}{|l|}{ Blood loss (ml) } \\
\hline$<1,000$ & 36 & 1 & & 1 & \\
\hline$\geq 1,000$ & 34 & $1.036(0.424-2.986)$ & 0.117 & $1.352(0.374-3.463)$ & 0.353 \\
\hline \multicolumn{6}{|l|}{ Blood transfusion (ml) } \\
\hline Without & 32 & 1 & & 1 & \\
\hline With & 38 & $1.008(0.532-1.787)$ & 0.733 & $1.453(0.834-2.564)$ & 0.656 \\
\hline \multicolumn{6}{|l|}{ Complications } \\
\hline Absent & 54 & 1 & & 1 & \\
\hline Present & 16 & $0.986(0.330-2.675)$ & 0.559 & $0.824(0.363-2.863)$ & 0.348 \\
\hline \multicolumn{6}{|l|}{ BMI } \\
\hline Normal weight & 55 & 1 & & 1 & \\
\hline Overweight/obese & 15 & $1.006(0.687-1.331)$ & 0.309 & $1.250(0.909-1.671)$ & 0.326 \\
\hline
\end{tabular}

*Number of patients. $P$ values shown in bold indicate statistical significance between groups. AFP, alpha-fetoprotein; BMI, body mass index; HR, hazard ratio. 
were similar between two two groups, except that the older group had more pulmonary infection after hepatectomy. This implies that hepatectomy for young patients with large $\mathrm{HCC}$ is safe. We also found that the cumulative overall and disease-free survival curves after hepatectomy showed no statistical difference between the young and the older groups. This implies that hepatic resection for young patients with large HCC is efficacious.

\section{Conclusion}

In conclusion, the clinicopathologic characteristics and the outcome for young patients with large HCC after liver resection were similar to that of the older patients, except for differences in infection through HBV and BMI. Liver resection for young patients with large HCC is safe and efficacious and should be recommended.

\section{Abbreviations}

AFP: alpha-fetoprotein; BMI: body mass index; HBV: hepatitis B virus; HCC: hepatocellular carcinoma.

\section{Competing interests}

The authors declare that they have no competing interests.

\section{Authors' contributions}

XYL and JFX carried out the data collection and analysis, drafted the manuscript. Both authors read and approved the final manuscript.

\section{Acknowledgements}

Thanks to Mengchao Luo for Polishing language.

Received: 22 December 2013 Accepted: 19 May 2014

Published: 3 June 2014

\section{References}

1. Jemal A, Bray F, Center MM, Ferlay J, Ward E, Forman D: Global cancer statistics. CA Cancer J Clin 2011, 61:69-90

2. El-Serag HB: Hepatocellular carcinoma. N Engl J Med 2011, 365:1118-1127.

3. Villanueva A, Hoshida Y, Battiston C, Tovar V, Sia D, Alsinet C, Cornella H, Liberzon A, Kobayashi M, Kumada H, Thung SN, Bruix J, Newell P, April C, Fan JB, Roayaie S, Mazzaferro V, Schwartz ME, Llovet JM: Combining clinical, pathology, and gene expression data to predict recurrence of hepatocellular carcinoma. Gastroenterology 2011, 140:1501-1512.

4. Mayer J, Auriol J, Muscari F: Worst prognosis of hypovascular hepatocellular carcinoma. J Hepatol 2010, 52:227.

5. Huang J, Hernandez-Alejandro R, Croome KP, Zeng Y, Wu H, Chen Z Hepatic resection for huge multinodular $\mathrm{HCC}$ with macrovascular invasion. J Surg Res 2012, 178:743-750.

6. Ariizumi S, Kotera Y, Takahashi Y, Katagiri S, Yamamoto M: Impact of hepatectomy for huge solitary hepatocellular carcinoma: impact of hepatectomy for huge solitary hepatocellular carcinoma. J SurgOncol 2013, 107(4):408-413.

7. Yang LY, Xu JF, Ou DP, Wu W, Zeng ZJ: Hepatectomy for huge hepatocellular carcinoma: single institute's experience. World J Surg 2013, 37:2189-2196

8. Wang HW, Hsieh TH, Huang SY, Chau GY, Tung CY, Su CW, Wu JC: Forfeited hepatogenesis program and increased embryonic stem cell traits in young hepatocellular carcinoma (HCC) comparing to elderly HCC. BMC Genomics 2013, 14:736.

9. Motavaf M, Safari S, Saffari Jourshari M, Alavian SM: Hepatitis B virus-induced hepatocellular carcinoma: the role of the virus x protein. Acta Virol 2013, 57:389-396.

10. McMahon BJ: Chronic hepatitis B virus infection. Med Clin North Am 2014 98:39-54.

11. Keane MG, Pereira SP: Improving detection and treatment of liver cancer. Practitioner 2013, 257:21-26.
12. Araujo OC, Barros JJ, Do ÓKM, Nabuco LC, Luz CA, Perez RM, Niel C, Villela-Nogueira CA, Araujo NM: Genetic variability of hepatitis B and C viruses in Brazilian patients with and without hepatocellular carcinoma. J Med Virol 2014, 86:217-223.

13. Sali S, Alavian SM, Foster GR, Keyvani H, Mehrnoosh L, Mohammadi N: Influencing factors on the outcome and prognosis of patients with HBV infection: seven years follow-up. Hepat Mon 2013, 13:e8743.

14. Yang $Y$, Jin L, He YL, Wang K, Ma XH, Wang J, Yan Z, Feng YL, Li YQ, Chen TY, Liu HL, Zhao YR: Hepatitis B virus infection in clustering of infection in families with unfavorable prognoses in northwest China. J Med Virol 2013, 85:1893-1899.

15. lavarone $\mathrm{M}$, Colombo $\mathrm{M}: \mathrm{HBV}$ infection and hepatocellular carcinoma. Clin Liver Dis 2013, 17:375-397.

16. Michelotti GA, Machado MV, Diehl AM: NAFLD, NASH and liver cancer. Nat Rev Gastroenterol Hepatol 2013, 10:656-665.

17. Rahman R, Hammoud GM, Almashhrawi AA, Ahmed KT, Ibdah JA: Primary hepatocellular carcinoma and metabolic syndrome: an update. World J Gastrointest Oncol 2013, 5:186-194.

18. Vansaun MN, Mendonsa AM, Lee GD: Hepatocellular proliferation correlates with inflammatory cell and cytokine changes in a murine model of nonalcoholic fatty liver disease. PLoS One 2013, 8:e73054

19. Tacke F, Yoneyama H: From NAFLD to NASH to fibrosis to HCC: role of dendritic cell populations in the liver. Hepatology 2013, 58:494-496.

doi:10.1186/1477-7819-12-175

Cite this article as: Liu and $\mathrm{Xu}$ : Liver resection for young patients with large hepatocellular carcinoma: a single center experience from China. World Journal of Surgical Oncology 2014 12:175.

\section{Submit your next manuscript to BioMed Central and take full advantage of:}

- Convenient online submission

- Thorough peer review

- No space constraints or color figure charges

- Immediate publication on acceptance

- Inclusion in PubMed, CAS, Scopus and Google Scholar

- Research which is freely available for redistribution 